\title{
Reel Revelations: Apocalypse and Film, edited by John Walliss and Lee Quinby
}

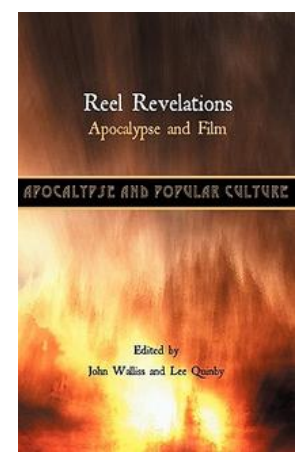

Apocalypse and Popular Culture I | The Bible in the Modern World 3 I | Sheffield: Sheffield Phoenix Press, 2010 | viii + I79 pages | ISBN: 978-I-907534-08-9 (hardback) $£ 50.00$

There are a number of superb essays in Reel Revelations: Apocalypse and Film, a short collection on the intersection of the biblical book of Revelation and contemporary film, which might leave the reader to wonder why the collection as a whole comes across as being rather underwhelming. In the final analysis, this is a distinctly uneven anthology in which the more rigorous and challenging work is sadly overshadowed by the presence of the weaker contributions. There is a wearying sameness to some of these essays, particularly when they are placed alongside the volumes of work done on religion and film in recent years. Does the world really need any more academic discussion about religious syncretism in The Matrix, especially as there are far more complex and socially relevant apocalyptic films-Alfonso Cuaron's 2005 masterpiece Children of Men comes to mind immediately - that have received very little serious scholarly attention? This sameness is even more apparent in the volume's overreliance on a small store of secondary sources, most notably the work of Conrad Ostwalt, who appears in six of the volume's nine essays. Why have these scholars collectively ignored classical works in the field-like Frank Kermode's The Sense of an Ending, which makes only sporadic appearances-as well as more sophisticated recent work, like S. Brent Plate's work on cinematic and religious world-building, particularly given that the necessary corollary of the destruction of Revelation is the building of a new, redeemed world?

The editors, John Walliss and Lee Quinby, open the volume with a brief introduction, which effectively underlines the multiple functions of Revelation in the twenty-first century West:

a surprising number of apocalyptic films from the past twentyfive years stay remarkably close to the traditional designation of apocalypse as a revelation about the future. Furthermore, many of them explicitly quote or use imagery from the Book of Revelation, as well as its Old Testament antecedents in Daniel, 
Ezekiel and Isaiah.... In so doing, some use the apocalyptic vision of Revelation to criticize certain social practices and power structures. Others do so in order to explore alternatives to the traditional apocalyptic paradigm and still others to rewrite it for a world already transformed, either through innovations in technology or post-apocalyptic wreckage. (2)

It is worth noting that most of the best essays in the collection focus on the ways in which contemporary apocalyptic films - whether they are horror, thriller, science fiction, or otherwise-often very subtly work to challenge or undermine social and religious absolutes, many of them inherited from the biblical Revelation.

In the excellent first chapter, "Apocalyptic Images and Prophetic Function in Zombie Films," Kim Paffenroth uses the zombie films of George Romero to bring out this capacity of end-times narratives to make trenchant social criticisms. Romero, with a keen cinematic eye and a thorough knowledge of recent American history, she argues, rails in his films against secular sins such as capitalism gone rampant, with its "crass and cannibalistic consumption" (2 I), and the persistent injustices of racism and nationalism. She calls I978's Dawn of the Dead, set largely in a suburban shopping mall (and arguably Romero's finest moment as a filmmaker), "one of the saddest and most damning critiques of consumerism imaginable" (I8). She takes her analysis a step further and argues that the zombie as re-imagined by Romero in his classic 1968 film Night of the Living Dead is an ideal metaphorical construct for making such criticisms:

The particularly horrible addition made by Romero is that zombies partially eat their victims. This not only enables the filmmaker or author to create scenes of grotesque cannibalism and dismemberment, but it also raises the symbolic stakes of the zombie. Unlike the seductive vampire, who bites his/her victim on the neck in a very sexualized gesture, the zombie tears other people limb from limb and flings their intestines into a steaming pile on the ground. There is nothing attractive or sensual about a zombie attack-it is animalistic and sickening. But since zombies look exactly like living human beings, their cannibalism also brings out the image of humanity preying on itself-the self-destructive and sadistic elements of all people, 
which have been seen on killing fields all across the "real" world even without a zombie virus to excuse the behaviour. (8)

In his relentless attack on the wrongs of the contemporary United States, Romero is, Paffenroth concludes, in his way very like the Hebrew Bible's Jeremiah. In his detailed depictions of hell (this time on earth), he is also, she argues, a bit like Dante.

Lee Quinby's second chapter, "Southland Tales, The Film of Revelation: Richard Kelly's Satire of American Apocalypse," is far and away the collection's high point, and not merely because it makes repeated and serious use of the phrase "new pimp messiah" (42). Quinby provides an incisive analysis of a film that actively resists any sort of systematisation, and one that requires an intrepid embrace of all of its revelatory strangeness. On Quinby's reading, Southland Tales is a "creative appropriation" of Revelation in a distinctly contemporary, and distinctly American, idiom; the film is

by turns sophisticated and naïve, almost always confusing, often hilarious, and a genuinely weird mix of cosmic time rifts, music videos, and conspiracies run amok... And yet, despite (and as I will argue because of) its cinematic chaos, Southland Tales deserves serious attention precisely because of the way the book of Revelation is deployed throughout. Kelly's unique blend of scriptural fidelity and secular focus provides an intriguing depiction of cultural and personal trauma stemming from uncomfortably familiar forms of calamity that have debilitated both the United States and its citizenry since 9/ I I .... To put this in terms of Kelly's vision, America is a traumatized society undergoing a split so deep that reality itself has been split asunder. $(27-8)$

He also takes a brief foray into the film's failure, both commercially and critically, and finds a fault line running through contemporary American culture: "what most blocked its reception was also its greatest insight- the use of the book of Revelation as the key text to comprehending that, as a society, America is mired in apocalyptic belief, perceiving itself as both victim and victor in a dynamic bent on destruction" (30).

The next chapter, Frances Flannery's "Post-modern Apocalypse and Terrorism in Joss Whedon's Serenity" is an ideal complement to Quinby's, despite the fact that Joss Whedon's film is a far simpler and less divisive text than 
Kelly's, in that both challenge the absolutism of Revelation. Instead, they use such absolutes as a way to criticise religious and political fundamentalisms: "Joss Whedon's Serenity deconstructs the apocalypse.... It invites audience members who shun fundamentalism as well as those who reject the tradition of violent apocalypse to consider a new, ambiguous vision of the rupture and repair of history" (44). Finding parallels between Serenity's abused psychic River Tam and John of Patmos, the chapter draws out the revelations contained within the diegetic world of the film-chiefly, that the interstellar empire of the Alliance, not unlike many terrestrial empires throughout history, is responsible for creating its own worst enemy.

After the collection's strong opening, the next essay, Jon R. Stone's “Apocalyptic Fiction: Revelatory Elements within Post-war American Films" comes disappointingly close to being a mere catalogue of recent revelatory and apocalyptic films. After some helpful comments about a genre he calls "apocalyptic fiction," Stone asserts that these films reveal, "a culture on the brink of nuclear, environmental, technological, and biological destruction" (6I). This is doubtlessly true, but one is forced to wonder what Stone adds to the larger discourse with the frankly pedestrian (not to mention very badly dated) insights he draws from this looming brink, including that "the 'silver screen' fulfils two purposes: it is at once a medium that displays images of interest and concern to the audience and at the same time a mirror that reflects back upon its viewers" (59).

Quite on the other hand, Mary Ann Beavis's "Pseudapocrypha: Invented Scripture in Apocalyptic Horror Films" is a fascinating addition to the collection and an interesting challenge to reception history in that it deals with the ways filmmakers have employed apocryphal religious texts in creating imaginaries of the end times. She examines I and 2 Enoch and the popular reception of both the Dead Sea Scrolls and the Nag Hammadi library in order to refine the relevant genre categories and problematise any simplistic understanding of apocalyptic films. Beavis shows, in ways that some of the other authors in Reel Revelations do not, an appreciation for the complexity of reception within apocalyptic films_- "As with many scriptures, canonical and otherwise, there are many intertextual resonances between these apocalyptic horror movies" (84) - making for vastly complicated chains of reference, reception, and re-reading.

John Walliss, venturing refreshingly far from the Hollywood mainstream in his "Celling the End Times: The Contours of Contemporary Rapture Films," explores the neglected area of films made by and for evangelical Chris- 
tians in the United States. After tracing the pre-history of the current glut of films as far back as I94I's The Rapture, Walliss summarises the uses these films serve for evangelical audiences, which are not as straightforward as they might seem:

the films utilize and adapt apocalyptic texts to convey a series of messages about a variety of religious and geopolitical issues that exercise their producers and audience, ranging from fears of a one-world global order and a resurgence of "old Europe," questions about the nature and certainty of salvation, an ambivalence towards technology and the mass media, and last but no means least, beliefs about the nature of "true Christianity" and the place of evangelical Christians in the contemporary world ... The films thus, in a manner akin to science fiction, allow both their producers and audiences to explore their present concerns and issues by projecting them into a near future where they will all be brought into stark relief. (92-3)

These films, Walliss points out, are nothing if not American, and they address specifically American evangelical fears of a resurgent Europe, the rise of the New Age, and many of the other bogeymen adopted by Evangelical Christians and more lately by Tea Party Republicans, all informed by the persecution complex that sees conservative Christians in even conservative, Christian contexts like the contemporary United States driven by a self-understanding of Christians as an embattled minority culture (all evidence to the contrary notwithstanding). Indeed, Walliss argues that it is from this tension that films like Left Behind and The Omega Code draw their considerable power: "rapture films are as much concerned with reinforcing and redefining the beliefs of their viewers, as they are with winning new souls. In particular, the portrayal of born again conversions may ... serve to reinforce viewers' convictions that they are themselves indeed saved" (I06).

"Sanctifying Empire: The Hopeful Paradox of Apocalypsia," by Richard Walsh, takes the collection further into political territory, offering further depth to Walliss's exploration of the evangelical Rapture film by demonstrating the ways in which even "secularised" apocalyptic films can serve to reinforce and justify conservative and even imperial politics. Walsh's reading moves in two directions at once, focusing equally on Revelation and on Peter Hyams's 1999 "unremarkable, boilerplate” film, End of Days. Walsh's conclu- 
sions about the "surreptitious sanctification of empire which occurs in both Revelation and End of Days" (I I 2) are challenging and compellingly argued:

Apocalyptic is essentially covenant maintenance in what is perceived as a hostile world. It reflects the purity regulations of a closed, traditional society. It is the ancient equivalent of a Patriot Act... Neither the film nor Revelation is a helpful site to address the problem of violence. Both avoid the issue. End of Days avoids it by withdrawing into subjective depths, which disregard the inherent messiness and violence of social-political reality, and Revelation avoids it by withdrawing in order to await God's violence on its behalf. Both leave the world mired in violence. ( $129-30)$

After Walliss's and Walsh's erudite discussions of the role of Revelation in the justification of empire, Reel Revelations would have been a far stronger collection if had ended at page I39, given that the weaknesses of the final two essays in the collection go some way towards obscuring the genuine insight and challenging conclusions of what came before. The failure of the penultimate essay, Greg Garrett's “'I Saw One Like a Son of Man': The Eschatological Savior in Contemporary Film," is merely that it is bland and adds little to the larger discussion. Here the seasoned reader can be forgiven for skipping quickly over yet another discussion of saviour figures (adding "eschatological" doesn't really add anything new), again seen through the lens of Ostwalt's Secular Steeples. The chapter presents a rather obvious analysis of rather obvious films and comes, not surprisingly, to rather obvious conclusions about how eschatological saviours, like The Matrix's Neo and the Terminator franchise's John Connor, achieve lasting popularity because they serve a social need or speak to current cultural concerns.

The final essay, Elizabeth Rosen's "More than meets the eye': Apocalypse Transformed in Transformers," far and away the weakest single chapter, ends the collection with a very T. S. Eliot-esque whimper. Its more serious failings point to the dangers inherent in doing this sort of work in a haphazard fashion. Though Rosen is to be commended for discussing a film that many critics in the academy would choose to dismiss, this does not excuse the fact that the idiosyncratic reading she offers of Michael Bay's Transformersis one that we can only label as an "aberrant decoding," to borrow a phrase from Umberto Eco. Rosen's choice to discuss the film within the context of 
the "postmodern refusal of absolutes" is deeply troubling, given the borderline fascist and determinedly racist and misogynist character of not only the Transformers series, but all of Bay's films. Even allowing for the open nature of all texts, there is really no way to argue seriously that Transformers deals in postmodern ambiguities. There is perhaps no filmmaker working today, in the mainstream or even in the evangelical sub-culture, who creates moral universes as starkly polarised as the "stunningly, even viciously untalented" Michael Bay (to borrow an apt description from The New Yorker's David Denby). ${ }^{8}$

To say that Bay is instead deeply implicated in American imperialism is not a mere assertion or an aesthetic judgement, particularly given the generally spectacular grosses Bay's films tend to generate in international markets; Bay's films, including Transformers, are invariably made with the full cooperation of the American military, and thus by definition must serve its interests. The Pentagon's stated criteria for offering military assistance to a film production-access to military property, equipment, and personnel—include that the film "helps military recruiting and retention" and offers "feasible" and "authentic" portrays of the armed forces; however, this authenticity is highly selective. Phil Strub, the long-time head of the Pentagon's film liaison office, once stated unequivocally that "any film that portrays the military as negative is not realistic to us." Thus, Bay's apologia for American militarism is caught up directly with the pursuit of empire. Transformers, in fact, would make an ideal film for the analyses of John Walliss or Richard Walsh, both of whom pay appropriate attention to Revelation's importance in the legitimisation and justification of empire.

That Rosen connects the film in her closing section with raising a world of children who are "less likely to be dogmatic" (I72), is particularly troubling, given that Bay's aestheticisation and even sanctification of empire works directly towards promoting a seductively lovely world which respects only political and economic dogmata. Rosen's reading of the film is inadequate to the complexity of the matter at hand. Even worse, her analysis ultimately obscures rather than illuminates the film's imperial ambitions and thus works directly against her own stated purpose. If we are to understand the trajectory and influence of Revelation in the world today, especially considering

${ }^{8}$ David Denby, “The Current Cinema-Tommy Guns and Toys: 'Public Enemies' and 'Transformers: Revenge of the Fallen'”, The New Yorker, and I 36 th July 2009, 93.

${ }^{9}$ Cited in David L. Robb, Operation Hollywood: How the Pentagon Shapes and Censors the Movies (New York: Prometheus Books, 2004), 5 I, I 8. 
the increasingly imperial ambitions of the United States, where so many of the most influential readings of the apocalypse are produced, we need to be serious-minded and politically astute, like Richard Walsh, Kim Paffenroth, Lee Quinby, and John Walliss elsewhere in this volume.

Rosen's final plea, for readings of Revelation that can lead to a more just world, brings to light a tension that underlies much of Reel Revelations, though rarely as explicitly as it is found here. Is it in the remit of biblical scholarship to find ways to redeem the most difficult of the New Testament texts by offering positive readings of it? Surely not. The task of biblical scholarship — and of reception history more generally - is to explore the trajectory Revelations has taken over the last two millennia, not to guide it to specified ends. When Richard Walsh, for example, argues convincingly that both Revelation and Hollywood blockbuster films leave the world mired in violence, it is time for lesser critics to take note; serious times with serious problems demand serious criticism. Nothing less will suffice.

Eric Repphun

University of Otago 